\title{
The analysis of financial liquidity management in small transport enterprises during the COVID 19 pandemic - case study of Poland
}

\author{
ROBERT WALASEK \\ Department of Management \\ Jan Kochanowski University in Kielce \\ Żeromskiego Street 5, Kielce 25-369 \\ POLAND \\ GRZEGORZ ZIMON \\ Department of Finance, Banking and Accounting \\ Rzeszow University of Technology \\ Al. Powstancow Warszawy 12, Rzeszow 35-959 \\ POLAND
}

\begin{abstract}
The crisis associated with the COVID-19 pandemic hit all industries in Poland. It is most noticeable for small and micro enterprises, which are particularly exposed to the risk of losing financial liquidity. Small payment bottlenecks, interruptions in production, sales or services, immediately affect the financial security of these entities. The COVID-19 pandemic has shaken the financial condition of virtually all service enterprises in Poland. Closing borders and quarantine forced on many entities hindered the flow of products in integrated supply chains, which significantly impacted the functionality of enterprises providing transport services. The purpose of this article is an attempt to present a strategy for managing liquidity in transport enterprises during the COVID-19 pandemic. The article presents strategies for managing liquidity in the period before the pandemic and during its first three months. The article presents selected mechanisms that were used by managers of small enterprises at the time of the appearance of the COVID-19 pandemic. The period of three months is too short a time to assess whether the tools used were effective and have brought measurable benefits, which is why this article is an introduction to the wider research that will be carried out in the future.
\end{abstract}

Key-Words: - Strategy, financial liquidity, management, transport, supply chain, enterprises.

Received: May 2, 2020. Revised: August 4, 2020 Accepted: August 25, 2020, 2020. Published: September 3, 2020.

\section{Introduction}

The innovativeness of economy means that an appropriate strategy supported by information technology becomes the main weapon in the fight for the competitive market position of the enterprise [1]. The situation is no different in the TSL branch, where transport is one of the most important sectors of the economy and the base of the logistics chain [2]. The European transport market is evolving intensively towards liberalization and efficiency of access, unification of economic, financial, technical and social relations, increase of interoperability and uniform rules of intraindustry and inter-industry competition. During the transport process, the object that is moved passes through the subsequent phases a complex and multi-phase technological procedure [3]. That's why, activities related to the implementation of a transport processes are primarily aimed at increasing competitiveness within the transport system and the efficiency of transport itself [4]. Despite the fact that the impact of transport projects is positive for all economies, there are significant differences when it comes to the benefits of participating in regional and global value chains [5]. 
Dynamic changes taking place in the business environment affect a wide variety of enterprise functioning-related processes. The factors that cause the biggest need for change in enterprises are the rapid economic changes caused by the geopolitical situation of the countries and the fast-growing pandemic of COVID-19 coronavirus. All over the world, the pandemic has caused very large falls in the economic climate of highly developed countries. According to OECD, due to COVID-19, the predicted global economic growth from the forecasted $2.9 \%$ will drop by $0.5 \%$ [6]. However, additional forecasts indicate that the decline may be even greater, to $1.5 \%$ in 2020 . The Institute of International Finance (IIF) confirms that the global DGP will be well below 2.6\% [7]. The downward trend is also observable in Poland, where the economic downturn is estimated at about $44 \%$, while the decrease in the general business climate (NSA) in transport and storage is minus $48.3 \%$. The most negative effects of the COVID-19 pandemic have significantly hit transport enterprises, especially those from the SME sector that deal with road transport in Poland. The collapse in the transport industry was slowly happening, triggered by the overlapping effect of changes on the domestic labor market and the introduction of administrative and legal barriers in many European Union countries. In addition, lobbying activities of many foreign groups resulted in restrictions on access to the European road transport market due to changes in the EU legislation. The climax of the steadily deteriorating situation in transport industry has become the global COVID-19 pandemic. Transport enterprises providing services for industrial sectors found themselves in the worst situation, because production in these industries was suspended or severely limited. This in turn affected the number of orders received at falling freight prices [8] and created the need for protective measures to ensure safety of transport and employees. Carriers, especially those from the SME sector, have problems with timely repayment of liabilities and maintaining profitability in the field of transport activity. According to Big Info Monitor and BIK data, at the end of 2019 Q3, every eleventh enterprise had outstanding commitments [9]. It can be concluded that in the near future these enterprises will face problems regarding their liquidity cushion, and this will make them classified as victims of the COVID-19 pandemic. Hence, the situation requires the creation of financial reserves and strategies that will allow to maintain positive working capital, which will increase financial liquidity [10-13]. The aim of the article is to analyze and evaluate financial liquidity management strategies in small transport enterprises during the COVID-19 pandemic.

\section{Strategic conditions of transport enterprises - literature review}

The geographic positioning in Central Europe means that Poland has one of the most important communication routes in Europe. Transit routes from Western Europe to Eastern Europe and towards East Asia, as well as the route from Northern Europe to the Mediterranean Basin, all cross here. That is why transport is of such strategic importance for Poland, crucial not only for the development of the state, but above all for the lives of its citizens. Currently, transport is dominated mainly by one branch - road transport, [14] which is referred to as the main carrier on the market [15]. In freight transport, its systematically but consistently increasing share now reaches around $84 \%$ of all land transport calculated in tons of transported cargo. According to the CSO report, in 2019, all types of transport carried more than 2.2 million tons of cargo, i.e. $1.3 \%$ more than a year ago, of which over 1.9 million tons by road, while the increase in passenger transport grew by $3.3 \%$ in the previous year [16]. Further increase in transport is also forecast in the years to come are [17]. This stems from the fact that the development of transport plays a key role in improving the attractiveness of regions and economies of virtually all countries [18-19]. The socio-economic development triggers changes in material and information flows in the global logistics chains. These changes also result from the need to adapt the services provided by logistics operators to the increasingly complex needs customers have [20]. The current slowdown in the implementation of transport services due to the COVID-19 pandemic and restrictions introduced by countries in free 
movement both in passenger and - to a lesser extent - in freight traffic, forced enterprises to adapt to the changing and unpredictable functioning conditions on the transport market. Virtually all transport enterprises have recorded decline in demand for transport services and for the use of the road network. This resulted from government restrictions imposed on citizens and on economic activity, as well as from concerns in the society. However, the COVID-19 pandemic has also confirmed the importance of road transport in the supplying and operation of emergency services in the fight against pandemics, and proved the importance of transport being operable [21]. Enterprises, seeking operability, are increasingly deciding to create and implement individual solutions aimed at absorbing modern knowledge, information and resources [22] that will allow them to maintain jobs and relative profitability.

Threats to transport enterprises, which result from the COVID-19 pandemic, force them to verify their approach to current financial management strategies in the supply chain, to avoid financial crisis. It is defined as a process, which includes less serious financial difficulties, bankruptcy liquidations and situations between the two extremes. The financial crisis of enterprises is a period concept with a start and ending, that is, starting from the moment that a financial crisis appears to the moment that an enterprise bankrupts [23]. Enterprises operating on the transport market are forced to change their liquidity management strategies from aggressive to conservative, i.e. those that will currently generate positive working capital and allow enterprises to function relatively efficiently at the expense of reducing operating profits. This approach is due to the fact that the company's working capital is a buffer that is designed to protect it against losing liquidity in the long run. Potential risks need to be sorted out, information collection and analysis should be strengthened and daily monitoring and analysis system should be established. The index system and analysis framework of risk warning with internal relations are established, and risk prevention measures are formulated to prevent the occurrence of financial crisis [24]. This approach is often recommended by scientific publications, in which one can often be convinced that the safest strategy for managing liquidity for enterprises is the conservative strategy [25-28].The main goal of this strategy is to create financial reserves ensuring security and high financial liquidity at the cost of lower profits of the enterprise [29]. The choice between profit and financial security are dilemmas currently faced by managers of virtually all transport enterprises. Currently, given the COVID-19 pandemic, the best choice for them will be to use conservative strategies that will not only allow them to function relatively well and preserve their jobs, but, most importantly, allow them to survive a difficult period. Using the so-far existing aggressive strategies for working capital management would not only fail to bring the intended effects, but also going away from controlling end recipients and extending the credit period for contractors might lead to bankruptcy. Therefore, managers of small enterprises operating in the transport industry should try to focus their current activities on strengthening the relationship with the customer by reducing the margin on freight. However, such actions should be carefully thought out and consulted with other entities with which the enterprise interacts in the transport market. Such activities should be based on the modification of financial liquidity management and on transition to conservatism in the implementation of the enterprise financial strategy.

One of such options in the strategic and financial area for transport enterprises is the implementation and practical application of new solutions, which on the one hand will be conducive to the technological development of the company, and on the other hand will reduce the costs of current operations for sake of financial liquidity. This situation is dictated primarily by a high degree of customer variability - their requirements and expectations in relation to the products purchased [30] and by current economic requirements. The element that will be necessary for transport companies to get out of the financial collapse will be the digitization of the transport market in four areas: basic digitization, market platformization, entering the markets of digital giants and the introduction and use of advanced digital technologies. 
According to the forecast, after 2022 such approach will increase the share of advanced solutions for telematics, artificial intelligence or blockchain-based solutions on the market [31]. In addition, the use of solutions from the digitization area will significantly reduce the enterprise operating costs and allow to maintain financial liquidity by establishing long-term relationships with customers and creating added value.

These types of solutions, aiming to improve the organizational efficiency of the transport system in Poland and Europe, affect many factors of the enterprise's functioning, including: market, financial and operational results, operating costs, efficiency and speed of logistic operations, use of resources as well as punctuality and credibility of business activities [32]. It is known that the effects of the COVID-19 pandemic will be felt for the transport industry for a long time after it ends. For some enterprises, new development opportunities will appear, while for others the pandemic will significantly contribute to business closure. From the point of view of road network resilience, a pandemic is an unwanted event with low probability of occurrence, but with significant economic and social consequences.

\section{Financial liquidity management analysis research methodology}

In literature, one may find a number of analyzes regarding the functioning of large and medium-sized transport enterprises in Poland and Europe ([33], [34], [35]). In this study, the authors have attempted to analyze the financial liquidity of small enterprises operating in the transport industry, whose annual turnover oscillates between PLN 4 million and PLN 12 million. The research analysis was dictated by the fact that small entities in Poland usually become victims of payment gridlocks, which leads to deterioration of their financial condition and, as a consequence, to the loss of financial liquidity. This, in turn, is the main reason for their bankruptcy. In the light of the above, it seemed important to conduct a study
The authors are very cautious about the presented analyzes, because it is too short a period to be able to talk about trends, and this study is only a preliminary forecast of the situation that occurs among small transport companies in Poland, and present the results regarding the assessment of liquidity management strategies that have been applied during COVID-19 in this group of enterprises. Such analysis is important from the point of view of their further development and overcoming the difficulties associated with the pandemic.

The main purpose of the study was to attempt an analysis of liquidity management strategies used for small transport enterprises before the pandemic and the structure of current assets during the COVID-19 pandemic. Emphasis was placed on identifying changes in the structure of financial assets and inventory turnover ratios. Additionally, the author analyzed the share of short-term investments and receivables in the company's current assets, as well as turnover ratios for enterprise liabilities. The sample selection for the study was random. The research method was a survey questionnaire distributed electronically. Based on the available databases and using specific selection criteria, a list of 150 small transport enterprises operating in Poland was created. After formal and substantive verification, 138 entities were qualified for the analysis. Only 31 of them participated in the study. The response rate was $22.4 \%$.

The analysis was divided into two stages. The first stage concerned financial liquidity management strategies used by the surveyed enterprises in 2016-2018. In turn, in the second stage, having financial data for the last three months (March-May 2020), the authors attempted to assess the method of managing liquidity in the face of changes caused by the COVID-19 pandemic. The financial data for the 2016-2018 analysis have been obtained from financial statements. On the other hand, data for the period of March-May 2020 came from a pilot study conducted among small transport enterprises. It should be emphasized that obtaining data for the study was extremely difficult due to restrictions and quarantine and limitations on the free movement of citizens introduced by the government. 
The study used analytical methods based mainly on relevant financial indicators. Basic statistical tools were also used, such as: arithmetic mean, median, standard deviations, maximum value and minimum value.

The authors are very cautious about the presented analyzes, as it is too short a period to be able to talk about trends. This study is only a preliminary forecast of the situation that occurs among small transport enterprises in Poland. The article tries to use the latest literature, but due to the short period that has passed since the COVID-19 outbreak, there are still gaps in the latest sources relating to the change in the financial situation of the small transport companies in Poland that have been operating during the pandemic.

\section{$4 \quad$ Financial liquidity management analysis - results}

Financial strategy improvement during the COVID-19 pandemic has become a priority for enterprises in their recovering from economic collapse. The situation before the pandemic was definitely more favorable. Enterprises did not have to deal with economic stagnation, and transport traffic related to inventory rotation was developing at a dizzying pace. Financial results achieved by enterprises translated to their financial security in the near future. Financial liquidity management was characterized by stability and the perspective of achieving profits above average value. Table 1 presents the results for the current and quick liquidity ratios.

Table 1. Average results for financial liquidity ratios in 2016-2018

\begin{tabular}{|l|c|c|c|c|c|}
\hline Index & $\bar{x}$ & $\mathrm{Me}$ & $s$ & $\min$ & $\max$ \\
\hline $\begin{array}{l}\text { Current } \\
\text { ratio }\end{array}$ & 2.51 & 2.20 & 0.75 & 1.30 & 3.30 \\
\hline $\begin{array}{l}\text { Quick } \\
\text { ratio }\end{array}$ & 2.05 & 1.83 & 0.67 & 1.20 & 3.10 \\
\hline
\end{tabular}

Source: own study

The above analysis shows that the average results of financial liquidity in small transport enterprises in the analyzed period remained at a similar level. In both cases, the results are high, which should be interpreted as positive. This applies especially to the Quick ratio indicator, in which current assets are receivables from customers and short-term investments. The presented results indicate the use of a safe strategy.

Taking the above trend into account, Table 2 presents the results regarding the structure of enterprises' current assets.

Table 2. Average results regarding the structure of current assets in the period of 2016-2018

\begin{tabular}{|l|c|c|c|c|c|}
\hline Index & $\bar{x}$ & Me & $s$ & $\min$ & $\max$ \\
\hline $\begin{array}{l}\text { Share of } \\
\text { receivables in } \\
\text { current assets }\end{array}$ & 0,53 & 0,61 & 0,24 & 0.28 & 0.82 \\
\hline $\begin{array}{l}\text { Share of short } \\
\text { investment in } \\
\text { current assets }\end{array}$ & 0,38 & 0,35 & 0,29 & 0.05 & 0.41 \\
\hline $\begin{array}{l}\text { Share of } \\
\text { inventory in } \\
\text { current assets }\end{array}$ & 0,09 & 0,04 & 0,08 & 0.01 & 0.33 \\
\hline
\end{tabular}

Source: own study

The analysis of the structure of current assets for the 2016-2018 period revealed that the two most important elements affecting the level of current assets in an enterprise are: short-term receivables and short-term investments. The analytical structure is dominated by short-term receivables, however, the share of short-term investments in the form of cash in hand or a bank account is quite visible. They constitute an average of about $38 \%$.

An extremely important issue in the analysis of managing the financial liquidity strategy of enterprises is the efficiency ratio measured in relation to a day. Table 3 presents rotational efficiency ratios.

Table 3. Average results for turnover ratios in the 2016-2018 period

\begin{tabular}{|l|c|c|c|c|c|}
\hline Index & $\bar{x}$ & $\mathrm{Me}$ & $s$ & $\min$ & $\max$ \\
\hline $\begin{array}{l}\text { Receivables } \\
\text { rotation in } \\
\text { dates }\end{array}$ & 56.47 & 62.1 & 29.77 & 35 & 112 \\
\hline
\end{tabular}




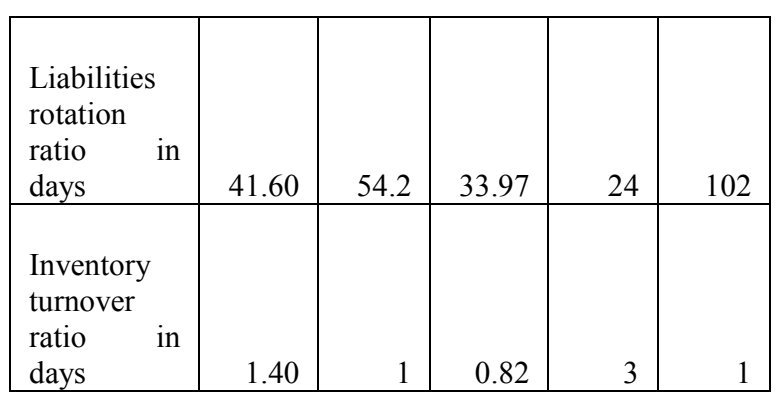

Source: own study

As the results show, enterprises recorded a faster rotation of short-term liabilities, calculated in days, in relation to short-term receivables. This is an unfavorable situation, because enterprises, understood as entities, are lenders to their recipients. They are obliged to regulate their obligations towards creditors in advance. On the other hand, receipts from receivables are obtained 15 days later on average. In the current situation, it is advisable to significantly change these relations. Shortterm receivables should affect the accounts of enterprises faster, or the payment period to creditors should be extended, which will undoubtedly contribute to improving the current situation regarding the financial liquidity of the enterprise.

The analysis and results presented in Tables 13 indicate that small enterprises operating in the transport industry apply a conservative and in some cases moderate-conservative approach to financial liquidity management. Focusing on moderate strategy is the result of the ratio of short-term payables towards market creditors being higher than the ratios of shortterm receivables and turnover. The only worrying thing is poor collection of short-term receivables in relation to short-term liabilities on the transport market.

In the second stage of the analysis, the authors attempted to assess financial liquidity management strategies used by transport enterprises in March-May 2020, i.e. during a pandemic in Poland. The initial COVID-19 lockdown duration was one of the most difficult periods for freight transport. Individual countries introduced different restrictions on movement, closed borders, directing traffic to one or two major border crossings with a given country. Other passages remained closed for transport or were closed for transit traffic. In addition, the situation at the intra-EU and non-EU borders, with huge queues, additional procedures and informational chaos, caused an increase in demand for freight, and, consequently, an increase in transport charges. It was no different in Poland, where the restrictions introduced by the Polish government resulted in a temporary suspension of business activity in virtually all industries, in particular in the service and manufacturing. The introduction of blockades and the closing of commercial businesses caused gaps in the supply chain, and thus there was stagnation in transport, which was also influenced by the refusal of drivers to carry out transport, as they feared for their own health or life. At present, the situation is stabilizing and the economies of many countries are gradually recovering. Numerous restrictions are being lifted and drivers have returned to work.

Due to the gradual return "back to normal", the most important change that could be observed in terms of managing liquidity of enterprises was the change in approach in managing shortterm receivables. Managers in many enterprises have applied limited trust strategies and reduced trade credit as much as possible. This resulted in faster rotation of short-term receivables. In the method of payment, enterprises began to prefer cash payments in order to eliminate the risk of emergence of debts that is difficult to collect. Table 4 presents the analysis of the structure of current assets for the period March-May 2020.

Table 4. Average results of current assets structure in March-May 2020

\begin{tabular}{|l|l|l|l|l|l|}
\hline Index & $\bar{x}$ & $\mathrm{Me}$ & $s$ & $\min$ & $\max$ \\
\hline $\begin{array}{l}\text { Share of } \\
\text { Receivables } \\
\text { in current } \\
\text { assets }\end{array}$ & 0.47 & 0.55 & 0.25 & 0.22 & 0.80 \\
\hline $\begin{array}{l}\text { Share of } \\
\text { Short } \\
\begin{array}{l}\text { Investment } \\
\text { in current } \\
\text { assets }\end{array}\end{array}$ & 0.44 & 0.40 & 0.29 & 0.05 & 0.51 \\
\hline
\end{tabular}

Source: own study

The change of the approach to receivables management policy in small transport enterprises caused a decrease in the average share of receivables from recipients, i.e. of 
short-term receivables. Due to this, the level of cash in hand or assets on the bank account increased. The authors did not undertake the analysis of rotation ratios in days, because the period in which the analysis was carried out was too short to be able to reliably determine this parameter. The analysis would not show any statistically significant difference, due to the fact that the average time period for receivables turnover is two months. The analysed short-term receivables turnover ratio and its results are primarily influenced by sales only for the month of March, from which the proceeds to bank accounts will appear only in April or May 2020.

In the further part of the study, the authors made a preliminary analysis of the financial liquidity of enterprises for the first three months of COVID-19 pandemic, i.e. MarchMay 2020. The results of the analysis are presented in Table 5.

Table 5. Average results for financial liquidity ratios in March-May 2020

\begin{tabular}{|l|l|l|l|l|l|}
\hline Index & $\bar{x}$ & $\mathrm{Me}$ & $s$ & $\min$ & $\max$ \\
\hline $\begin{array}{l}\text { Current } \\
\text { ratio }\end{array}$ & 2.53 & 2.21 & 0.76 & 1.50 & 3.00 \\
\hline $\begin{array}{l}\text { Quick } \\
\text { ratio }\end{array}$ & 2.09 & 1.90 & 0.67 & 1.40 & 2.70 \\
\hline
\end{tabular}

Source: own study

The results obtained from the analysis indicate that a slight increase in financial liquidity ratios could be observed among the studied enterprises. One could see a real increase in cash on hand or bank account statements. This is confirmed by the immediate liquidity ratio. It shows the ratio of short-term investments to short-term liabilities. The results are presented in Table 6.

Table 6 . The results of the immediate liquidity ratios

\begin{tabular}{|l|c|c|c|c|c|}
\hline Index & $\bar{x}$ & $\mathrm{Me}$ & $s$ & $\min$ & $\max$ \\
\hline $\begin{array}{l}\text { Instant } \\
\text { liquidity ratio } \\
-\quad \text { period: } \\
2016-2018\end{array}$ & 0.11 & 0.10 & 0.32 & 0.08 & 0.31 \\
\hline Instant liquidity & 0.23 & 0.16 & 0.29 & 0.06 & 0,42 \\
\hline
\end{tabular}

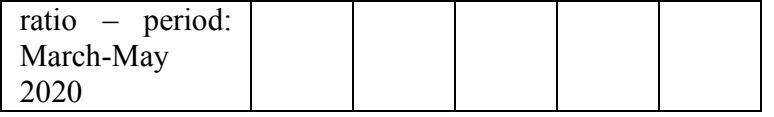

Source: own study

Higher financial liquidity of enterprises was recorded in the period March-May 2020. This is due to the increase in the level of short-term investments. The conclusion of this trend is that there is a gradual liquidation of assets in the form of receivables in return for the possession of monetary assets.

The narrowed conclusions, that have been achieved, result from the limited availability of information and studies presenting statistical data relating to the activities of the transport industry in the world during COVID-19. Due to the difference in the actual timing of the pandemic worldwide, different types of restrictions were applied around the world and implemented at various times as well. Some countries have used total lockdown methods, others have only partially closed borders and imposed restrictions on the transport industry. Thus, a statistical comparison of the financial liquidity of enterprises operating in other countries or continents is currently very difficult. The authors intend to attempt such an analysis in mid-2021, based on financial data for the entire year 2020

\section{Conclusion}

The research analysis is an introduction to the broader research that will be carried out in the future. This article is important from the perspective of liquidity management of small transport enterprises, because it shows the direction of changes introduced by managers in this area. These studies will be able to be continued when companies prepare financial statements for the entire 2020. In the future, the authors are trying to make a comparative analysis and analyze the dependencies that will undoubtedly appear after the expiry or neutralization of COVID-19. They will mainly concern changes in the economic and financial conditions of small transport enterprises after the pandemic is over, and thus the return of enterprises to the level of functionality before the pandemic. In the future, the authors also intend to investigate the influence of the main forces that might shape road transport in Poland in the coming years. The direction of 
further research will be dictated by the limitation of the pandemic or its neutralization, as this will result in a rapid revival of entrepreneurship in practically all countries. Entrepreneurs will strive to rebuild their economic position as soon as possible and return to the level of financing before COVID19. This will significantly affect the increase in domestic transport in terms of imports and exports. However, with the existing problems related to the shortage of drivers, this may be difficult and slow down the financial growth of enterprises. In addition, due to the change in EU law on the mobility package, which is to enter into force after 2022, a reorganization of international transport will happen, and thus a decrease in road transport performance. Entrepreneurs will look for a reduction in costs and cost optimization in the development of autonomous vehicles, alternative drive technologies and process automation through the use of various systems, including: ERP, TMS, WMS etc.

Preliminary research analyzes have confirmed that there is a trend among transport companies to change their liquidity management strategy towards conservative management. The direction of changes result from the concerns of entrepreneurs regarding maintaining financial liquidity in the long run, and by that, avoiding payment gridlocks that may cause them to fall. Enterprises changed their financial policy in relation to managing short-term receivables. Therefore, they began to effectively enforce payment claims from creditors. Shortening the payment period will allow enterprises to reduce the cost of financing their recipients, which in turn will improve profitability. Improving profitability, on the other hand, will allow for obtaining additional funds, and this will certainly increase financial liquidity.

In addition, they introduced the principle of limitation in the way payments are made for services, preferring cash payments. Due to these activities, in the analyzed period of three months of the pandemic period, a slight decrease was observed in the receivables from customers due to the increase in cash on hand or in bank accounts. Such a liquidity management policy should be seen as positive. It is true that when analyzing liquidity management strategies in 2016-2018, one can conclude that enterprises used a moderately secure financial liquidity strategy. The current situation related to COVID-19 has verified their actions towards strategic conservatism in order to defend the company against bankruptcy. Although these activities are risky from the point of view of profitability, they are directed by the managers of enterprises to the implementation of their currently most important goal, which is to ensure continuation of business operations and a relatively smooth recovery from the recession.

The research presented in the article was only intended to present the initial situation of Polish small transport enterprises in relation to the financial liquidity management strategy in the time of the COVID-19 pandemic. The initial study revealed a new situation for transport companies after the government imposed a lockdown on global movement. To a large extent, it constitutes a new look at the shaping of financial liquidity of small transport enterprises in Poland. It also formulates a certain conceptual cause-and-effect model in theoretical terms, relating to the adaptation of transport companies to the economic situation resulting from the COVID-19 pandemic. The results of the conducted analysis show a certain change in the approach of transport companies to limitations in financial liquidity, which is applicable not only in Poland, but also may relate to the situation of transport companies in other European countries. They can also be used at the level of various institutions to evaluate and revise the existing lockdown policy.

\section{References:}

[1] Walasek, R., Post-transactional customer service in a company's competitive approach - results of the study, Prace naukowe Uniwersytetu Ekonomicznego we Wroclawiu, Vol. 63, No. 5, 2019, p. 200.

[2] Przybylska, E., Analiza usługi transportowej w wybranym przedsiębiorstwie sektora TSL, Zeszyty Naukowe Politechniki Śląskiej, seria: Organizacja $i$ Zarzadzanie, No. 56, Wydawnictwo Politechniki Śląskiej, Gliwice, 2011, p. 240.

[3] Starkowski, D., Analiza procesu przewozowego i zasady planowania 
operacji transportowej na podstawie wybranego przedsiębiorstwa transportowego podczas przewozu płatów rybnych. Cz. 2, Teoretyczne zasady planowania operacji przewozowej, Autobusy: technika, eksploatacja, systemy transportowe, No. 6, 2016, p. 1576.

[4] Liberadzki B., Mundur L., Zarys polityki transportowej państwa, [w:] Nowe wyzwania - nowe rozwiązania, Materiaty konferencyjne Polskiego Kongresu Logistycznego „Logistics 2008”, Biblioteka Logistyka, Poznań, 2008, p. 238.

[5] Sadowski A., Wąsowska, K., Nowak I., Logistics Development in European Countries: The Case of Poland, European Research Studies, 23(2), 2020, p. 505.

[6] OECD Economic Outlook, Vol. 2020 Issue wer.elektroniczna:https://www.oecdilibrar y.org/sites/0d1d1e2een/index.html?itemId $=/$ content $/$ publication $/ 0 \mathrm{~d} 1 \mathrm{~d} 1 \mathrm{e} 2 \mathrm{e}-\mathrm{en}$.

[7] Pandemia uderza w transport drogowy, (2020).

wer.elektroniczna:https://www.tslbiznes.pl/newsy/pandemia-uderza-wtransport-drogowy/

[8] Trans.Info(2020).https://trans.info/pl/kons olidacja-rynku-transportowegoprzyspieszy-przez-epidemie-covid-19182149

[9] BIG Info Monitor, (2020). Powolne hamowanie rozpędzonego transport, wer. elektroniczna:

https://www.money.pl/gielda/big-infomonitor-9-1-firm-transportowych-czekana-zalegle-platnosci6474995239549057a.html.

[10] Dankiewicz R., Simionescu M., The insurance market in Romania: A macroeconomic and a microeconomic approach, Transformations in Business and Economics, Vol.19, No 1 (49), 2020, pp.248-260.

[11] Huang W., Mazouz K., Excess cash, trading continuity, and liquidity risk, Journal of Corporate Finance, Vol. 48, 2018, pp. 275-291.

[12] Ooghe H., De Prijcker S., Failure processes and causes of company bankruptcy: a typology, Management Decision, Vol.46 (2), 2008, pp. 223-242.
[13] Zimon D., Zimon G., The Impact of Implementation of Standardized Quality Management Systems on Management of Liabilities in Group Purchasing Organizations, Quality Innovation Prosperity-Kvalita Inovacia Prosperita, Volume: 23, Issue: 1, 2019, pp. 60-73.

[14] Melo P.C., Graham D.J., Brage-Ardao R., The Productivity of Transport Infrastructure Investment: a Metaanalysis of Empirical Evidence, Regional Science and Urban Economics, Vol.43, (5), 2013, pp. 695-706.

[15] Świtała M., Zowada K., Foltyński M., Transport intermodalny w Polscekierunki i bariery rozwoju $\mathrm{z}$ uwzględnieniem perspektywy usługodawców logistycznych, Studia Ekonomiczne, nr 357, 2018, pp. 108-121.

[16] Przewozy ladunków i pasażerów w 2019 $r$., Gtówny Urząd Statystyczny, Warszawa, 2020, pp. 1-6

[17] Strategia Zrównoważonego Rozwoju Transportu do 2030 roku, Ministerstwo Infrastruktury RP, Warszawa, 2019, wer. elektroniczna:

https://www.gov.pl/documents/905843/10 47987\%20/Strategia Zr\%C3\%B3wnowa \%C5\%BConego_Rozwoju_\%20Transport u_\%28Projekt $\% 20$ z_dnia_9_listopada_2 $0 \overline{1} 8 \_$r $\% 29 . p d f / b 1 e \overline{2}$ b 8 cc-e $0 \mathrm{c} 8-1 \mathrm{e} 7 \mathrm{f}-$ $22 \mathrm{~b} 34 \mathrm{~d} 90 \mathrm{aa} 6 \mathrm{a} 1832$.

[18] Hlotywa A., Ndaguba E.A., Assessing the Impact of Road Transport Infrastructure Investment on Economic Development in South Africa, Journal of Transport and Supply Chain Management, Vol. 11, (1), 2017, pp. 1-12

[19] Shi Y., Shen G., Sun P., The Role of Infrastructure in China's Regional Economic Growth, Journal of Asian Economics, Vol. 49, C, 2017, pp. 26-41.

[20] Przybylska E., Żebrucki Z., Kruczek M., Identyfikacja czynników rozwoju transportu intermodalnego w Polsce, Zeszyty Naukowe Politechniki Ślaskiej, seria: Organizacja $i$ Zarzadzanie, No. 103, Gliwice, 2017, p.196.

[21] PIARC (2020). Dalsze wnioski po COVID-19, wer.elektroniczna:https://kongresdrogowy .pl/post/676-piarc-dalsze-wnioski-pocovid-19.

[22] Chieh-Yu L., Determinants of the adoption of technological innovations by 
logistics service providers in China, International Journal of Technology Management and Sustainable Development, Vol.7, No.1, 2008, p. 22.

[23] Zhang Zhuo, Wang Jia, Financial Model Based on Principle Component Analysis and Support Vector Machine, International Journal of Circuits, Systems and Signal Processing, Vol.13, 2019, p. 184.

[24] Duan Xiaohua., Systematic Risk Measurement Based on CoVaR Model, International Journal of Circuits, Systems and Signal Processing, Vol. 13, 2019, p. 243.

[25] Speranza M.G., Trends in transportation and logistics, European Journal of Operational Research, 264 (3), 2018, pp. 830-836.

[26] Rohanova H., Kravchenko I., Forecasting the availability of the working capital of the enterprise, Efektyvna ekonomika, [Online], Vol. 2, 2020, available at: $\mathrm{http} / / / \mathrm{www} \cdot$ economy.nayka.com.ua/?op= $1 \& z=7670$ (Accessed 02 Jul 2020). DOI: $10.32702 / 2307-2105-2020.2 .79$.

[27] Zimon G., Management Strategies of Working Capital in Polish Services Providing Companies, WSEAS Transactions on Business and Economics, Vol.17, 2020, pp. 225-230.

[28] Carbo-Valverde S., Rodriguez-Fernandez F., Udell G.F., Bank market power and SME financing constraints, Review of Finance Vol.13, 2009, pp. 309-340.

[29] Petersen M.A., Rajan R.G., Trade credit: theories and evidence. Review Finance Studies, Vol.10, 1997, pp. 661-691.

[30] Walasek R., Supply chain optimization and competitiveness of an enterprise results of the study, Research Logistic and Production, Wyd. Politechniki Poznańskiej w Poznaniu, Poznań, Vol 6, No. 2, 2016, p. 178.

[31] PwC, Raport o perspektywach rozwoju transportu drogowego w Polsce w latach 2020-

2030,wer.elektroniczna:https://www.pwc. $\mathrm{pl} / \mathrm{pl} /$ publikacje/2019/transportprzyszlosci-perspektywy-rozwojutransportu-drogowego-w-polsce-20202030.html

[32] Ferrando A., Mulier K., Do firms use trade credit channel to manage growth?
Journal Banking and Finance, Vol. 37, 2013, pp. 3035-3046.

[33] Zhuravskaya M., Morozova E., Anashkina N., Ingaldi M., Toyotaoriented technologies as ecological management tools for transport enterprises, Polish Journal of Management Studies, Vol.13, Issue 2, 2016, p. 192-203.

[34] Perzyńska A., Witkowski K., The use of instruments of logistics and marketing in transport enterprises in Lubuskie voivodeship, LogForum, Vol.12, Issue 3, 2016, pp. 307-316.

[35] Barcik R., Bylinko L. Transportation demand management as a tool of transport policy, Transport Problems: International Scientific Journal, Vol.13 Issue 2, 2018, pp. 121-131.

\section{Contribution of individual authors to the creation of a scientific article (ghostwriting policy)}

Robert Walasek, Grzegorz ZimonConceptualization

Robert Walasek, Grzegorz Zimon - writingreview and editing

Robert Walasek, Grzegorz Zimon was responsible for the Statistics.

Robert Walasek, Grzegorz Zimon writingoriginal draft preparation

\section{Creative Commons Attribution License 4.0 (Attribution 4.0 International, CC BY 4.0)}

This article is published under the terms of the Creative Commons Attribution License 4.0 https://creativecommons.org/licenses/by/4.0/deed.en US 